\title{
Humidification during laparoscopic surgery: overview of the clinical benefits of using humidified gas during laparoscopic surgery
}

\author{
Maria Mercedes Binda ${ }^{1}$
}

Received: 2 October 2014/Accepted: 2 April 2015/Published online: 25 April 2015

(C) The Author(s) 2015. This article is published with open access at Springerlink.com

\begin{abstract}
Purpose The peritoneum is the serous membrane that covers the abdominal cavity and most of the intra-abdominal organs. It is a very delicate layer highly susceptible to damage and it is not designed to cope with variable conditions such as the dry and cold carbon dioxide $\left(\mathrm{CO}_{2}\right)$ during laparoscopic surgery. The aim of this review was to evaluate the effects caused by insufflating dry and cold gas into the abdominal cavity after laparoscopic surgery.

Methods A literature search using the Pubmed was carried out. Articles identified focused on the key issues of laparoscopy, peritoneum, morphology, pneumoperitoneum, humidity, body temperature, pain, recovery time, post-operative adhesions and lens fogging.

Results Insufflating dry and cold $\mathrm{CO}_{2}$ into the abdomen causes peritoneal damage, post-operative pain, hypothermia and post-operative adhesions. Using humidified and warm gas prevents pain after surgery. With regard to hypothermia due to desiccation, it can be fully prevented using humidified and warm gas. Results relating to the patient recovery are still controversial.

Conclusions The use of humidified and warm insufflation gas offers a significant clinical benefit to the patient, creating a more physiologic peritoneal environment and reducing the post-operative pain and hypothermia. In animal models, although humidified and warm gas reduces postoperative adhesions, humidified gas at $32{ }^{\circ} \mathrm{C}$ reduced them
\end{abstract}

Maria Mercedes Binda

Mercedes.Binda@uclouvain.be; Mercedes.Binda@gmail.com

1 Institut de Recherche Expérimentale et Clinique (IREC), Pôle de Gynécologie, Avenue Mounier 52, bte B1.52.02,

1200 Brussels, Belgium even more. It is clear that humidified gas should be used during laparoscopic surgery; however, a question remains unanswered: to achieve even greater clinical benefit to the patient, at what temperature should the humidified gas be when insufflated into the abdomen? More clinical trials should be performed to resolve this query.

Keywords Laparoscopy · Pneumoperitoneum · Humidity · Body temperature · Pain · Post-operative adhesions

\section{Basics of the physiology of the peritoneum}

The peritoneum is the serous membrane that forms the lining of the abdominal cavity and it covers most of the intra-abdominal organs. It is composed of a single layer of mesothelium, generally $2.5-3 \mu \mathrm{m}$ thick, supported by a thin layer of connective tissue [1]. With a surface area of some $14,000 \mathrm{~cm}^{2}$ in adults [2], almost equal to that of the skin, this membrane may be the largest organ in humans. Its function is to diminish the friction among abdominal viscera, enabling their free movement. It also walls off infection and serves as a reservoir of fat, especially in the omentum. It contains two distinct layers of collagen, and it is one of the most richly vascularised of all organs. The membrane comprises very large amounts of mucopolysaccharides or glycosaminoglycans and just beneath its surface there is an elastin layer that gives the peritoneum mobility. The surface lining of the peritoneum consists of highly differentiated mesothelial cells [3].

Mesothelial cells are predominantly flattened, squamous-like, approximately $25 \mu \mathrm{m}$ in diameter, with the cytoplasm raised over a central round or oval nucleus [4]. Long microvilli are projected from the apical surface of the 
mesothelial cells [1]. They have well-developed cell-to-cell junctional complexes including tight junctions, adherent junctions, gap junctions and desmosomes. Tight junctions, in particular, are crucial for the development of cell surface polarity and the establishment and maintenance of a semipermeable diffusion barrier [4]. They secrete glycosaminoglycans, proteoglycans and phospholipids to provide a slippery, non-adhesive glycocalyx that protects the serosal surface from abrasion, infection and tumour dissemination. In addition, mesothelial cells can synthesise cytokines, chemokines, growth factors and matrix components that regulate inflammation, initiate cell proliferation, differentiation and migration, and mediate tissue repair [5]. Providing scaffolding for the mesothelial cells are connective tissue proteins, and abundant vascular channels deliver oxygen and other nutrients to them. Interspersed among the connective tissue, there are extremely poorly differentiated and epithelioid-like cells similar to fibroblasts. These cells can undergo a variety of differentiation changes after exposure to injury or other types of stimuli, perhaps becoming mesothelial cells during peritoneal repair [3].

In summary, the peritoneal surface has a very important function in the abdominal cavity, i.e. to diminish the friction, wall off infection and to enable the secretion of cytokines. However, it is a very delicate layer and, therefore, highly susceptible to being damaged.

\section{Laparoscopic surgery}

Laparoscopy induces less direct trauma because of gentle tissue handling, meticulous haemostasis, constant irrigation, the use of microsurgical instruments and the smaller operative field. This procedure has been associated with less post-operative pain, less systemic immunological depression, less wound infection, fewer complications, faster bowel recovery, shorter hospital stays and earlier return to normal activities; however, the operating times can be longer in comparison to those in open surgery [6-11].

Typically, during laparoscopic surgery, the abdominopelvic cavity is first inflated with a gas to provide a space for viewing the surgical site and manipulating instruments. $\mathrm{CO}_{2}$ is used almost universally as the insufflation agent to create this space called the laparoscopic pneumoperitoneum. $\mathrm{CO}_{2}$ is the most common gas used for insufflation because of safety and supply reasons. First, it is non-combustible, eliminating the risk of fire when electrosurgical instruments are used, and second, it is cheap and highly soluble in water [12]. Solubility is important as any gas trapped in the body following surgery must be removed. $\mathrm{CO}_{2}$ dissolves into the serous fluid then migrates into the bloodstream where it travels to the lungs and is breathed out; therefore, $\mathrm{CO}_{2}$ can easily be removed from the body without any major effect on the body's metabolism. This high solubility in water reduces the risk of gas embolism impairing cardiac function.

The peritoneum is not designed to cope with variable conditions such as the introduction of dry and cold gas. Any change in the environment has an impact: the larger the deviation from physiologic intra-abdominal conditions, the larger the effect. Thus, the type of gas insufflated in the abdominal cavity $\left(\mathrm{CO}_{2}\right.$ or other gases), the nature of the gas (its temperature and humidity), the pressure and the extent of exposure to this gas (combination of time and volume of the gas) are factors that cause tissue damage.

Currently, dry $\mathrm{CO}_{2}$ gas at room temperature is used for insufflation. However, significant evidence suggests the use of humid and warm gas may reduce at least two of the major morbidities associated with laparoscopic surgery: post-operative pain and hypothermia [13, 14]. Humidifying insufflation gas provides a more physiologically normal pneumoperitoneum. This is a logical progression towards minimising trauma in line with the philosophy of laparoscopic surgery. These principles can also be extended to other types of endoscopic surgery where other cavities are inflated to enable surgery, i.e. gastrointestinal endoscopy [15], thoracoscopic [16], colonoscopic [17], and hysteroscopic [18] procedures and open surgery [19-23]. In these situations, the tissue desiccation is of equal consequence.

A great deal of clinical research has been carried out in this area with regard to clinical outcomes such as postoperative pain, hypothermia, post-operative adhesions, recovery time and optical clarity. A summary of this research follows.

\section{General impact of the standard $\mathrm{CO}_{2}$-induced pneumoperitoneum on the body}

When the standard dry and cold gas is insufflated into the warm abdomen, the gas is humidified and warmed up to reach an equilibrium of humidity and temperature, within the peritoneum. This means that the gas is warmed up until its temperature is equal to that of the peritoneum and it is humidified until it is as humid as the peritoneum. Both processes affect the patient's condition and, more specifically, that of the peritoneum. As a consequence, the peritoneum will lose temperature and liquid to reach this equilibrium with the dry and cold gas, and this process consumes energy and consequently induces hypothermia $[24,25]$. This hypothermia is mainly due to the energy spent to humidify the dry gas (577 cal to vaporise $1 \mathrm{~g}$ of water) rather than to the energy required to warm the cold gas $\left(0.00003\right.$ cal to heat $1 \mathrm{~mL}$ of $\mathrm{CO}_{2}$ by $\left.1{ }^{\circ} \mathrm{C}\right)$ [26]. Therefore, the pneumoperitoneum will systematically 
induce hypothermia [25, 27-29] that is, to a large extent, caused locally by the pneumoperitoneum-induced desiccation [30].

Other systematic effects produced by the $\mathrm{CO}_{2}$-induced pneumoperitoneum are the $\mathrm{CO}_{2}$ absorption from the abdominal cavity, causing acidosis and hypercarbia [31-35], which, if not compensated adequately for ventilation, can negatively affect the cardiovascular and respiratory functions [35, 36]. Moreover, $\mathrm{CO}_{2}$-induced pneumoperitoneum impairs venous return, depending on the intra-abdominal pressure [37], and decreases splanchnic perfusion with resulting oxidative stress [38]. Last but not least, $\mathrm{CO}_{2}$-induced pneumoperitoneum is associated with post-operative pain [39].

Other local effects produced by the $\mathrm{CO}_{2}$-induced pneumoperitoneum are the alteration of the peritoneal fluid [40] and induction of peritoneal acidosis [35], which may mediate suppression of peritoneal macrophage function [41]. In addition, $\mathrm{CO}_{2}$ alters the peritoneal microcirculation, decreasing the reactive oxygen species (ROS) scavengers [42], modulates the local immune system and the inflammatory reaction [43], and inhibits the peritoneal plasmin system, leading to peritoneal hypofibrinolysis.

As discussed above, the insufflation gas produces local and systematic effects and these side effects depend specifically on the nature of the gas: dry or humidified, cold or warm. In the following sections, the local and systematic effects will be discussed taking into account the nature of the insufflation gas.

\section{Impact of the insufflation gas on body temperature: hypothermia}

Temperatures throughout the body are integrated by a thermoregulatory system that coordinates cold and warm defences and keeps core temperature within $0.2{ }^{\circ} \mathrm{C}$ of timeadjusted normal values [44]. General anaesthesia produces marked and dose-dependent inhibition of thermoregulatory control in a three-phase pattern. Hypothermia initially results largely from core-to-peripheral redistribution of body heat that occurs when anaesthesia inhibits tonic thermoregulation vasoconstriction. Subsequently, heat loss exceeding metabolic heat production decreases core temperature in a slow, linear fashion. Finally, a core temperature plateau results when emergence of thermoregulatory vasoconstriction decreases cutaneous heat loss and constrains metabolic heat to the core thermal compartment [45].

In addition to anaesthesia-induced hypothermia, there is another source of heat loss during laparoscopic surgery: the dry and cold insufflation gas. It had been assumed that the impact of laparoscopy would be to decrease the risk of heat loss in comparison with an open surgery [46]. During open surgery, a large area of the abdomen is exposed to air whereas during laparoscopy the abdomen is sealed. However, the abdomen is not sealed off from the laparoscopic environment. In fact, the abdomen will be in contact with the dry and cold $\mathrm{CO}_{2}$ and, as explained above, the gas reaches equilibrium in humidity and in temperature within the wet and warm peritoneum. Therefore, the peritoneum will lose water and temperature to reach this equilibrium, which consumes energy and consequently induces hypothermia in the patient [24, 25].

Since there are adverse clinical effects due to core temperature cooling, hypothermia should be carefully monitored [47]. Hypothermia can cause complications such as post-operative shivering, increased duration of post-anaesthetic recovery and of hospitalisation, myocardial complications, increased surgical wound infection, intra-operative blood loss, impaired platelet and immune functions, including $\mathrm{T}$ cell-mediated antibody production and non-specific oxidative bacterial killing by neutrophils [48].

There are numerous studies comparing the effect of different gas conditions upon hypothermia, i.e. several studies comparing the use of warm and humidified gas with the standard dry and cold gas [13, 25, 49-55], a few using dry gas comparing cold vs warm [24, 28, 56-60], two studies comparing the four gas conditions [27, 61] and two studies using standard, humidified and cold and humidified and warmed $\mathrm{CO}_{2}[62,63]$.

Research into the effect of heating the dry gas to body temperature has led to mixed results. Heating the insufflation gas has been shown to reduce hypothermia [28, 56, 57], to provide no thermal benefit [24, 58, 59] and, conversely, to actually produce hypothermia [60].

When the effect of four kinds of gas (dry and cold, dry and warm, humidified and cold, humidified and warm) upon body temperature was analysed, insufflation with warm, dry gas did not prevent hypothermia; in addition, when cold $\mathrm{CO}_{2}$ was humidified, the decrease in core temperature was smaller than when cold, dry gas was used [27]. In a clinical trial, Davis et al. [61] analysed these four types of gas showing no differences in body temperature. However, it has to be taken into account that the study was undertaken with obese patients who have relatively less surface area from which to dissipate metabolic heat during the initial hour of surgery; therefore, the risk of intra-operative hypothermia was lower [45].

Hypothermia can be fully prevented using humidified and warm gas, as shown in animal models [25-27, 63, 64], in clinical trials [65] and as confirmed in a meta-analysis in humans [13]. However, Schlotterbeck et al. [62] have demonstrated that cold humidification of insufflating $\mathrm{CO}_{2}$ prevents heat loss associated with pneumoperitoneal insufflation as efficaciously as warmed humidification of the 
gas. The same conclusion was reached by Corona et al. [66], demonstrating that desiccation could be eliminated while maintaining the intra-peritoneal temperature between 31 and $32{ }^{\circ} \mathrm{C}$ without affecting core body temperature by insufflating humidified gas at $32{ }^{\circ} \mathrm{C}$ into the abdominal cavity. In this randomised control trial (RCT), an additional cooling to maintain temperatures of $31-32{ }^{\circ} \mathrm{C}$ in the peritoneal cavity - and avoiding desiccation-was needed and this was accomplished by nebulising $3 \mathrm{~mL} / \mathrm{min}$ of water at room temperature or at $0{ }^{\circ} \mathrm{C}$ with a nozzle set. These results show that the use of humidified insufflating gas, whether heated or cold, prevents specific heat loss compared with the use of standard dry and cold insufflation gas during abdominal laparoscopy. This is consistent with the observation that much more energy is used to humidify the gas than is needed to heat it. Almost the same amount of energy is required to humidify the gas to full saturation whether the gas entering is dry at $21{ }^{\circ} \mathrm{C}$ or dry at $37{ }^{\circ} \mathrm{C}$ [46].

It is also interesting to note that the dry nature of the gas has an effect more pronounced than the gas temperature in terms of body temperature loss. Although the resulting energy loss from the body is low [67] it is the dry nature of the gas rather than the energy loss which has a more significant effect. External warming devices are effective at maintaining temperature, but cannot assist in correcting the desiccating nature of the dry gas. Whether cold or warmed, dry gas can cause cell desiccation; in fact, the warmer the gas the greater the capacity for evaporation as the gas can "hold" more water vapour. Therefore, the peritoneum will dry out faster, which potentially leads to greater adverse effects $[46,59,68]$. Only gas at body temperature and fully saturated will prevent any loss of energy from the peritoneum surface because it is physically impossible to evaporate into a fully saturated gas. As a result, the fluid layer will be maintained, minimising any energy lost from the body and, therefore, eliminating the hypothermia induced by the evaporative losses in laparoscopic surgery. In addition, several studies using humidified insufflation gas have shown that the intra-abdominal temperature has been maintained [26, 27, 52].

The surgical community is still unclear on the clinical efficacy of only heating the insufflation gas as opposed to heating and humidifying this gas. In 2002, an expert panel from The European Association for Endoscopic Surgery (EAES) published a guideline on clinical recommendations for the pneumoperitoneum during laparoscopic surgery [69]. At that time, they postulated that the clinical benefits of humidified and warmed insufflation gas were minor and contradictory. In 2006, this guideline was updated but they still postulated that "the possible and small effect of warm and humidified insufflation gas is not justified" [70]. However, research on this topic has continued from 2006, leading to supportive evidence of the benefit of using humidified and warm gas as can be seen in two meta-analysis documents published in 2008 [13, 14].

In summary, maintenance of temperature or at least a reduction in temperature loss has been demonstrated using humidified and heated gas [13, 25, 27, 65].

\section{Impact of the insufflation gas on pain levels}

It is believed that much of the pain associated with surgery comes from the incision, however, the association between pain and wound size is not well researched. One study has demonstrated that patients with larger acute wounds reported higher pain intensity scores [71]. It is possible that when the area of the wound is larger, more nociceptors (the sensory receptors that cause the perception of pain) are activated and sensitised [72].

Through the use of laparoscopic surgery, the wound size can be reduced to only a few centimetres, considerably reducing pain and recovery time [73]. Because incision wound pain has been reduced by laparoscopic surgery, other sources of pain have become more significant and so now need to be addressed. There is evidence to suggest that the dominant source of pain and discomfort after laparoscopy is coming from the peritoneum rather than from the skin or abdominal wall [39]. One of these sources is the gas used for insufflation during laparoscopic surgery.

The cause of gas-related pain following laparoscopic surgery is multimodal. Apart from the wound size, the following points are known to be contributing factors in varying degrees: $[74,75]$.

\section{Distension-induced neurapraxia of the phrenic nerves and pain}

To allow sufficient access for the operation, insufflation pressure is usually kept at around $15 \mathrm{mmHg}$; this produces stretch-induced damage of nerves supplying the diaphragm, which possibly contributes to post-operative pain.

Type of insufflated gas and acidic intra-peritoneal environment and pain

The $\mathrm{CO}_{2}$ dissolution produces intra-abdominal acidosis which may damage the phrenic nerves and produce pain [74]. Although $\mathrm{CO}_{2}$ is the gas most used, other types of gas have been employed during laparoscopy, i.e. nitrous oxide $\left(\mathrm{N}_{2} \mathrm{O}\right)$, helium $(\mathrm{He})$, argon $(\mathrm{Ar})$, air and nitrogen $\left(\mathrm{N}_{2}\right)$ [76].

Pure $\mathrm{N}_{2} \mathrm{O}$ was the gas preferred by gynaecologists for pneumoperitoneum in the 1970s and 1980s as $\mathrm{N}_{2} \mathrm{O}$ shares several advantageous properties with $\mathrm{CO}_{2}$, i.e. an 
inexpensive gas, rapid elimination, and has similar levels of diffusion and solubility. It also has anaesthetic and analgesic properties, without having the cardiopulmonary side effects of $\mathrm{CO}_{2}[77,78]$. However, $\mathrm{N}_{2} \mathrm{O}$ behaves like air in the presence of high concentrations of combustible gas and electrical charge and it does not suppress the risk of combustion. Due to these properties, together with two case reports of intra-operative explosion associated with its use, $\mathrm{N}_{2} \mathrm{O}$ has been effectively banned in therapeutic laparoscopy [79, 80]. If there is a bowel perforation and gases such as methane escape from the intestinal area and are ignited by electrosurgery, some explosion risk exists. However, this risk only exists when the concentration of $\mathrm{N}_{2} \mathrm{O}$ is higher than $29 \%$ [81].

Aitola et al. [82] studied the effect of using pure $\mathrm{N}_{2} \mathrm{O}$ induced pneumoperitoneum upon post-operative pain. They have demonstrated that in those patients, from whom $\mathrm{N}_{2} \mathrm{O}$-induced pneumoperitoneum was used, less pain was experienced 1 and $6 \mathrm{~h}$ post-operatively, as well as during the next morning, in comparison with the patients for whom $\mathrm{CO}_{2}$-induced pneumoperitoneum was used. These results were also confirmed by a prospective single [83] and a prospective double-blind RCT [84] and by a recent meta-analysis [78]. In addition, the total amount of anaesthetic needed was lower in the $\mathrm{N}_{2} \mathrm{O}$ group and there were no side effects as acidosis was observed using $\mathrm{N}_{2} \mathrm{O}$ induced pneumoperitoneum [82]. Moreover, the mean endtidal $\mathrm{CO}_{2}$ increase was greater (despite a greater mean intra-operative increase in minute ventilation) and there was a substantial fall in the arterial $\mathrm{pH}$ for the patients in the $\mathrm{CO}_{2}$-induced pneumoperitoneum group. These phenomena were not observed in the $\mathrm{N}_{2} \mathrm{O}$ group [83] suggesting that $\mathrm{CO}_{2}$-induced acidosis may be involved in peritoneal irritation resulting in pain. In an RCT in deep endometriosis surgery [85], full-conditioning (86\% $\mathrm{CO}_{2}$ $10 \% \mathrm{~N}_{2} \mathrm{O} 4 \% \mathrm{O}_{2}$ for the pneumoperitoneum, cooling of the peritoneal cavity to $32{ }^{\circ} \mathrm{C}$, humidification), heparinised rinsing solution and $5 \mathrm{mg}$ of dexamethasone showed reduced post-operative pain, together with a lower $\mathrm{CO}_{2}$ resorption and less inflammation (lower C-reactive protein concentrations), in comparison to that of the $\mathrm{CO}_{2}$ pneumoperitoneum group. In this trial, it was postulated that the pain was mainly reduced by adding a small amount of $\mathrm{N}_{2} \mathrm{O}$ to the pneumoperitoneum, however, the effect of dexamethasone and local cooling upon pain cannot be excluded.

It is believed that helium-based pneumoperitoneum induces less post-operative pain due to its properties of being an inert gas, which has a more limited effect on intraabdominal $\mathrm{pH}$ and metabolism in comparison to the use of $\mathrm{CO}_{2}$ [86]. However, when helium-induced pneumoperitoneum was used, patients reported similar pain scores to those under $\mathrm{CO}_{2}$-induced pneumoperitoneum [12, 78, 86].
Fewer cardiopulmonary changes were observed with helium-induced pneumoperitoneum than $\mathrm{CO}_{2}$-induced pneumoperitoneum and there were no significant differences in cardiopulmonary complications and surgical morbidity [78]. Interestingly, O'Boyle et al. [86] studied the effect of helium and $\mathrm{CO}_{2}$-induced pneumoperitoneum together with the effect of saline lavage upon pain. Less pain was found in the group undergoing saline peritoneal lavage, demonstrating the importance of keeping the abdominal cavity wet.

In summary, there is an association between $\mathrm{CO}_{2}$-induced intra-peritoneal acidosis and pain. This acidosis might be avoided using helium or $\mathrm{N}_{2} \mathrm{O}$ insufflation gas. However, more clinical studies are needed to confirm the validity and safeness of these gases during laparoscopic surgery. In spite of the $\mathrm{CO}_{2}$-induced acidosis, $\mathrm{CO}_{2}$ is the most common gas used and nothing is known about the other gases, i.e. argon, nitrogen and air, and their relation with post-operative pain.

\section{Residual intra-abdominal gas after laparoscopy and pain}

Shoulder tip pain can be understood by considering the effect of residual $\mathrm{CO}_{2}$ gas. After surgery, a volume of insufflation gas remains in the peritoneal cavity for up to 3 days [87] and tends to collect at the top of the cavity under the diaphragm [88]. These gas bubbles are thought to irritate the diaphragm and the phrenic nerve, thus leading to subcostal pain. Because the nerves of the shoulder and the diaphragm exit the spine in the same bundle, irritation in one area can cause the brain to sense pain at both sites. Clinical studies showed that the severity and duration of post-operative pain was proportional to the amount of $\mathrm{CO}_{2}$ that remained in the pneumoperitoneum after laparoscopic surgery [88, 89].

Benefits from removal of this gas can be seen using an intra-peritoneal drain, which showed a decrease in the frequency of shoulder pain and a reduction in the postoperative analgesia requirements after laparoscopy [90, 91]. However, a study showed that post-operative pain was significantly increased in patients who had a drain in position compared with those in the non-drained group [92]. In addition, drains can produce some complications, such as an increase in wound infection rates and a delayed hospital discharge [93].

A quantification of the removal rate of gas bubbles has been undertaken by Glew et al. [94] and it was shown that gas bubbles can be removed significantly faster using humidified gas. Humidifying the gas can assist in the removal of residual $\mathrm{CO}_{2}$ due to its high solubility. To migrate through the tissue into the bloodstream, the gas needs to be dissolved in a fluid. The dry nature of the gas causes evaporation of the serous fluid. The remaining fluid is 
viscous [40], reducing the dissolving rate of the $\mathrm{CO}_{2}$; thus, the gas remains in the peritoneal cavity longer. It has been shown that using humidified insufflation gas, the serous fluid in the peritoneum will remain moist [40] facilitating the dissolving of $\mathrm{CO}_{2}$ and absorption out of the peritoneum faster, therefore reducing post-operative pain [88].

It is also known that there is a "suction effect" between the diaphragm and the liver and this is interrupted following surgery. This effect can be explained by means of an easy example, i.e. when a piece of paper is placed over a glass of water and the glass is inverted, the paper is held in place. Much of the weight of the liver is carried in a similar fashion, so the load of the liver is distributed across much of the upper peritoneal cavity. It has been proposed that the gas remaining in the peritoneum after insufflation interrupts this suction facility shifting more of the load to the mechanical fastenings between the liver and the diaphragm $[75,87,95]$. The resulting localised strain is then a source of irritation to the diaphragm and a likely cause of subcostal and referred shoulder tip pain. Support to this "suction effect" hypothesis is given by the location of the liver within the right hypochondriac region and by the observation that pain is often more severe in the right shoulder tip and the right subcostal areas. Humidification of insufflation gas helps return suction support sooner by preventing evaporation of the fluid on peritoneal and liver surfaces, and by faster removal of the gas pocket [94] causing the loss of suction. Some studies have shown partial success in correcting for the suction effect by spraying the peritoneal cavity with saline [87].

In summary, the residual intra-abdominal gas remaining after the surgery produces post-operative pain and an interruption to the suction effect; both can be improved using humidified gas.

\section{Temperature and humidification of the insufflated gas and pain}

The effect of the insufflation gas temperature upon postoperative pain is controversial [59, 75, 96, 97]. Korell et al. [97] demonstrated that the use of dry and warm gas reduced pain levels in a prospective randomised study. In another clinical trial, the effect of three gas conditions (humidified and heated; dry and heated; standard dry and cold gas) upon post-operative pain was investigated and no significant difference in intra-operative and post-operative analgesic requirements or post-operative pain score was found [96] There was even a tendency (although not significant) toward less pain and higher post-operative satisfaction among patients in the control group (standard dry and cold gas). However, a criticism to this study is the small sample size $(n=53)$. On the other hand, another prospective, controlled, randomised, double-blind study demonstrated that using humidifiedwarm gas for laparoscopic gastric banding reduces shoulder pain, and decreases pain medication requirements for up to 10 days post-operatively in comparison with gas conditions used for the other groups. In addition, dry-heated gas may cause additional complications since this increases pain medication use and pain intensity [98]. In this study, the sample size was bigger $(n=113)$.

In another study, it was demonstrated that patients receiving heated dry gas had more early post-operative pain than those in the control group using room temperature gas, suggesting that heated gas has no benefit in terms of pain reduction [68]. The authors suggested that the drying effect of the gas could be the cause. Consistent with this, the shoulder tip and subcostal pains were more intense after using warm gas during laparoscopy [59].

A possible explanation to the results obtained by the last three studies can be due to the characteristics of a dry gas. It is known that the capacity of a gas to retain water depends on its temperature: the higher the temperature, the more water a gas can hold. Therefore, when a dry gas enters the abdominal cavity, desiccation will inevitably occur [30] and it will increase at higher temperatures. In addition, the peritoneum has a large surface with a thin serous fluid layer which facilitates humidification of the pneumoperitoneum gas. As a result, a heated gas will produce more desiccation in the abdominal cavity than does a room temperature gas and this peritoneal damage may cause more pain.

With regard to the use of humidified gas, many clinical studies have demonstrated that patients receiving humidified and heated insufflation gas experienced less postoperative pain. This can be seen in a variety of procedures: laparoscopic cholecystectomy [51], several conscious [99, 100] and unconscious gynaecological procedures [50], several thoracoscopic procedures [16], gastric bypass [101], and a further study with Nissen fundoplication showed a beneficial trend but due to the low number of patients did not reach statistical significance [52]. Moreover, two meta-analyses have been published showing that patients in the humidified and warm insufflation gas group experienced a significant reduction in pain score after surgery, and in their analgesic requirements than did those in the control group which had standard cold and dry $\mathrm{CO}_{2}$ $[13,14]$.

For shorter surgeries, such as acute laparoscopic appendectomy, it was found that using humidified gas does not impart any clinical benefit on post-operative pain, on intra-operative core temperature and on post-operative recovery parameters in paediatric patients [102]. 
Tissue drying, peritoneal damage and post-operative pain

The exact relation between the level of tissue damage and post-operative pain is difficult to determine. Several animal studies have shown that dry and cold gas is deleterious for the peritoneum, i.e. it destroys the microvilli, causes the mesothelial cells to retract and bulge and exposes the basal lamina [27, 64, 65, 103-106]. Interestingly, these alterations depend on the duration of gas insufflation [107] and the insufflation pressure and type of gas [108]. When humidified and heated $\mathrm{CO}_{2}$ is used, fewer changes to the peritoneal layer were observed in comparison to using dry and cold gas in rats $[64,103]$ and in pigs [65]. However, two studies did not observe any improvement of the peritoneal surface after humidified $\mathrm{CO}_{2}$ insufflation [27, 94]. In the Hazebroek et al. study, anaesthesia was induced and maintained with repeated intra-peritoneal injections of pentobarbital sodium. Thus, some of the observed damage could be attributed to the direct effect of pentobarbital on the peritoneal surface. In the Glew et al. study, the samples were analysed by light microscopy, a technique less sensitive than the scanning electronic microscopy.

There is only one clinical trial in which the four types of gases were used in patients and both peritoneal morphology and pain scores were evaluated [61]. In this trial, peritoneal samples were taken at the beginning and at the end of the surgery, and no difference in either the pain scores or in the peritoneal morphology was found. This led the authors to postulate that "heating or humidifying of $\mathrm{CO}_{2}$ is not justified for patients undergoing laparoscopic bariatric surgery". However, this trial has several limitations, i.e. the sample size, power of the study and data collection, which can lead to erroneous conclusions [109].

In summary, although the exact relation between tissue damage and post-operative pain is difficult to determine, it is clear that dry and cold gas damages the peritoneum and that both pain and tissue damage are avoided using humidified gas.

\section{Volume of the insufflated gas and pain}

Pain increases with the gas consumption, a fact which led to the belief that the pain is caused by a physical effect [110]. For instance, it was demonstrated that the volume of the $\mathrm{CO}_{2}$ insufflated is an important factor in the cause of pain since post-operative pain levels increased with a high insufflation rate [111] but not with the duration of the surgery [112]. This indicates that the level of desiccation may be the contributing factor.

\section{Pressure used to induce the pneumoperitoneum and pain}

It was demonstrated that insufflation pressure significantly increased the post-operative pain associated with laparoscopic cholecystectomy [113, 114].
In summary, pain during surgery can be produced by several sources: the distension of the phrenic nerves, the type of insufflated gas and acidic intra-peritoneal environment, the residual intra-abdominal gas, the temperature and humidification of the insufflated gas, the tissue drying and the volume and pressure of the insufflated gas. Many of the factors causing post-operative pain listed at the beginning of this section can be reduced by humidifying and heating the gas.

\section{Impact of the insufflation gas on cellular integrity and tissue damage}

As explained in the section above regarding "Tissue drying, peritoneal damage and post-operative pain", the thin layer of mesothelial cells covering peritoneal surfaces is partly or completely damaged when dry gas is used, i.e. microvilli are destroyed, cells become retracted and bulged, the intercellular clefts increase in size and the basal lamina is exposed [27, 64, 65, 104, 105, 107, 115, 116], and this can be reduced using humidified and warm gas $[64,65,103,116]$.

This damage can be explained by the fact that when the insufflation gas exits the cannulae into the peritoneum and the gas travels as a jet stream until it reaches the wall of the peritoneum or an organ, where it is deflected [117]. Exit velocities approached $30 \mathrm{~m} / \mathrm{s}$ when the hydraulic diameter was $3 \mathrm{~mm}$ and differential pressure was $12 \mathrm{mmHg}$. If the gas is dry, fluid is evaporated off the tissue in the localised region where the gas impinges; this evaporation causes a severe cooling and tissue drying which results in tissue damage and pain [30, 118].

This mode of tissue damage is not possible if the gas is already saturated with water vapour. When the gas is holding water at $100 \%$ relative humidity $(\mathrm{RH})$ at the same temperature as the surrounding tissue (around $37^{\circ} \mathrm{C}$ ), no further water can be absorbed. Evaporation from the serous fluid will not occur and cooling and cell desiccation will not take place [30]. Evaporation of serous fluid from the peritoneal surface due to the dry gas also causes less severe but much wider spread tissue damage in the rest of the peritoneum.

Following the peritoneal trauma due to the desiccating nature of the dry gas, an inflammatory reaction is produced, as demonstrated in several animal models. Two hours after a laparoscopy was performed with dry and cold $\mathrm{CO}_{2}$, an inflammatory cell infiltration in the parietal and visceral peritoneum was observed [119]. Volz et al. [104] showed that, $12 \mathrm{~h}$ after the laparoscopy, peritoneal macrophages and lymphocytes filled all gaps, recovering the basal lamina, as confirmed by Davey et al. [116]. These results in animal models were confirmed in humans by Liu et al. [107], demonstrating that $2 \mathrm{~h}$ after dry $\mathrm{CO}_{2}$ insufflation a 
small amount of lymphocytes and macrophages were found in the intercellular clefts.

Moreover, the degree of inflammation will also depend on the type of gas and the insufflation pressure used during laparoscopy. Paparella et al. [108, 119] demonstrated that air-induced pneumoperitoneum produces more inflammation than $\mathrm{CO}_{2}$-induced pneumoperitoneum by evaluating the following features of the peritoneal surface: congestion, haemorrhage, oedema, and inflammatory cells and their location of the lamina propria and submucosal, and mesothelial cells looking for hyperplasia, metaplasia and hypertrophy. They also demonstrated that at higher insufflation pressure the inflammation is greater [108]. The trauma associated with the higher insufflation pressure was also demonstrated by the group of Matsuzaki et al. [120, 121] that showed that a low intra-peritoneal pressure $(8 \mathrm{mmHg})$ would be better than the standard intra-peritoneal pressure $(12 \mathrm{mmHg})$ to minimise the adverse impact on the surgical peritoneal environment, and on the peritoneal fibrinolytic system during a $\mathrm{CO}_{2}$ pneumoperitoneum [122].

When dry-heated $\mathrm{CO}_{2}$ was insufflated, some animals showed little or no alteration of the mesothelial layer, while others had a mild inflammatory response and mesothelial cells were rounded and showed crenation on the exposed surface; when insufflation was performed with heated and humidified $\mathrm{CO}_{2}$, specimens showed little change when compared with those within the control group [116]. Humidified and heated gas reduces the inflammatory response as seen in the reduction of tumour necrosis factor alpha (TNF- $\alpha$ ) [94]. In addition, another study has shown that the use of humidified gas diminishes the increased lymphocytes which occurred during laparoscopy [103]. This shows that less trauma occurs in the peritoneum with humidified gas.

Interestingly, Corona et al. [123] have demonstrated that manipulation of the upper bowel during laparoscopy induced with $\mathrm{CO}_{2}$ increased acute inflammation at the abdominal cavity in comparison to those in the control group without using manipulation. This shows the importance of good surgical practice.

\section{Impact of the insufflation gas on the recovery time}

The time taken for a patient to recover from surgery is an important issue. Any time saved at each point of recovery also contributes to a reduction in the cost of treatment and the quality of life of the patient.

\section{Recovery room stay}

Directly after surgery, a patient is transferred to the recovery unit until they are sufficiently stable and conscious to be transferred to a normal ward or to return home. A patient's fitness to be discharged from recovery is based on factors such as respiratory and circulatory baselines, body temperature and levels of consciousness and pain. In the case of a healthy patient, hypothermia and pain are the factors most likely to require a patient to stay longer in the recovery ward. Reduced hypothermia and decreased pain levels (by faster removal of gas and less trauma to the peritoneal tissue) mean that a patient will require less time to recover.

Two studies have shown that patients who received humidified insufflation gas during surgery spent significantly less time in the recovery unit $[50,98]$. It was shown that $89 \%$ of patients with humidified gas stayed in the recovery unit less than $1 \mathrm{~h}$, but only $33 \%$ of patients

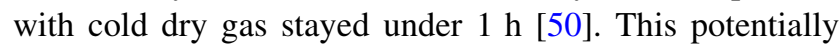
reduces "bottlenecks" in the recovery department and costs. However, several studies did not find any significant differences in the recovery room stay using humidified gas [55, 61, 124]. Manwaring et al. [124] suggested that external warming blankets may be more effective in maintaining intra-operative normothermia than the use of heated humidified gas.

\section{Hospital stay}

Some studies have shown that the use of humidified insufflation gas leads to a shorter hospital stay when compared to cold dry insufflation gas [54]. This can translate to significant cost benefits for the hospital. However, several studies did not show any benefit in the length of hospitalisation when humidified gas is used compared with dry and cold gas usage $[16,52,53,55,61]$ information confirmed by a meta-analysis [13].

\section{Return to normal activities}

After a patient is discharged from hospital, there is a recovery period before they are able to return to normal daily activities and work. It has been shown that if humidified and warm gas is used during laparoscopic cholecystectomy procedures, the recovery time to recommence normal activities can be reduced and it was halved compared to the use of standard cold and dry $\mathrm{CO}_{2}$ insufflation gas [51]. However, two studies did not show any significant differences using humidified gas [53, 125].

In summary, although it is clear that humidified and warm gas prevents hypothermia and pain after surgery, results related to the patient recovery are still controversial. Of course the recovery time depends on several factors, i.e. patient characteristics, surgeon skills, type and duration of the surgery, and makes this topic difficult to fully evaluate. 


\section{Impact of the insufflation gas on post-operative adhesions}

\section{Definition, aetiology and incidence of intra-peritoneal adhesions}

Adhesions are abnormal fibrous connections between surfaces within body cavities. Many different insults, such as infections, surgery, chemical irritation, endometriosis and dry gas, can disrupt the peritoneum, produce inflammation and develop adhesions [126]. Such adhesions can be classified, according to the aetiology, in congenital or acquired, either post-inflammatory or post-operatively [127]. Abdominal surgery is the most common cause of adhesions; the incidence ranges from 63 to $97 \%$ [127-129]. Some $10 \%$ of patients without having had previous surgery have adhesions (92\% post-inflammatory and $8 \%$ congenital). In contrast, adhesions are found in $93 \%$ of patients with at least one previous surgery (98\% post-operative, $1 \%$ postinflammatory and $1 \%$ congenital) [128].

\section{Clinical significance of intra-peritoneal adhesions}

Adhesions are the major cause of intestinal obstruction [130, 131], of female infertility [132, 133], chronic pain, and difficulties at the time of re-operation. The burden of postoperative adhesions is best illustrated by the study showing that $5.7 \%$ of all readmissions of patients undergoing open abdominal or pelvic surgery were classified as being directly related to adhesions, and $3.8 \%$ of the patients were managed operatively [127]. In addition, $34.6 \%$ of the patients who underwent open abdominal or pelvic surgery were readmitted 2.1 times over 10 years for a disorder directly or possibly related to adhesions and $22.1 \%$ of all outcome readmissions occurred in the first year after initial surgery. Last but not least, the financial consequences of the adhesions are enormous, i.e. adhesiolysis hospitalisations during 1988 in USA accounted for US\$1180 million in healthcare expenditures, with US\$925 million going towards in-hospital expenses and US\$255 million for surgeon fees [134].

\section{Pneumoperitoneum as a cofactor in adhesion formation}

It has been claimed that laparoscopy is less adhesiogenic than laparotomy but the data are inconclusive. Animal studies indicate that laparoscopy could induce less adhesion formation [135-138], whereas other studies fail to show differences [139-141]. In humans, laparoscopy could induce less de novo adhesion formation [142, 143] but for adhesion reformation, this also remains controversial [142145].

To interpret this data, it is important to highlight the differences between laparoscopy and laparotomy in terms of the direct trauma induced by the surgery itself and the indirect trauma that might be induced by the peritoneal environment. If performed adequately by well-trained surgeons, laparoscopy should induce less direct surgical trauma because of gentle tissue handling, meticulous haemostasis, constant irrigation, the use of microsurgical instruments and the smaller operative field, which may reduce the risk of adhesion formation. On the other hand, laparoscopy and laparotomy are performed in different gas environments: $\mathrm{CO}_{2}$ for the former and air for the latter. Indeed, as explained above, the peritoneum is not designed to cope with the variable conditions of the pneumoperitoneum. Thus, the type of gas used to induce the pneumoperitoneum, the nature of the gas (temperature and humidity) and the pressure can all cause tissue damage which results in an increase in adhesion formation.

It has been postulated in studies of mice and rabbits that $\mathrm{CO}_{2}$-induced pneumoperitoneum is a cofactor in adhesion formation [146-148]. In these models, standardised lesions were performed during laparoscopy and the effect of different factors with regard to the pneumoperitoneum (duration, gas type, pressure, humidified or dry gas) has been studied. It was demonstrated that adhesions increased with duration of pneumoperitoneum and with insufflation pressure [146, 148-150]. Furthermore, a reduction of adhesions has been observed when a small amount of oxygen (3-4 \%) is added to both $\mathrm{CO}_{2}$ and helium-induced pneumoperitoneum in rabbits $[149,150]$ and mice $[146,148]$. Therefore, it was assumed that the $\mathrm{CO}_{2}$ pneumoperitoneum-enhanced adhesions could be mediated by mesothelial hypoxia. The beneficial effect of the addition of 3-4\% oxygen can be explained by the fact that the mesothelial cells would be in a more physiologic (normoxic) environment [151, 152]. This hypothesis is supported by the observation that during $\mathrm{CO}_{2}$ or helium-induced pneumoperitoneum, the partial pressure of oxygen in the abdominal wall was reduced [153]. Moreover, this is consistent with the result of Matsuzaki et al. [154] showing that a perioperative oxygen supplementation at the ventilation reduced post-operative adhesion formation through increasing the peritoneal tissue oxygen tension.

In addition, the relation between $\mathrm{CO}_{2}$ pneumoperitoneum-induced acidosis/hypercarbia and adhesion formation has also been addressed in a laparoscopic mouse model in which animals with endotracheal intubation were mechanically ventilated with different patterns [32]. Adhesion formation was higher in animals poorly ventilated and decreased with higher ventilation rates. In comparison with animals that underwent anaesthesia only, the $\mathrm{CO}_{2}$ induced pneumoperitoneum increases the $\mathrm{pCO}_{2}$ and decreases the $\mathrm{pH}$, as has been reported in animal models [31, 34, 155] and humans [36]. These effects were more pronounced in poorly ventilated mice and counteracted by 
appropriate ventilation (i.e. higher ventilation rates). These data demonstrate an association between $\mathrm{CO}_{2}$ pneumoperitoneum-induced acidosis/hypercarbia and adhesion formation. However, the mechanism whereby this acidosis/ hypercarbia becomes a cofactor in adhesion formation remains unclear. Obviously a trauma produced by the acidosis/hypercarbia upon mesothelial cells and molecules involved in adhesion formation cannot be excluded. Indeed, acidosis affects lymphocyte and macrophage functions altering cellular and humoral immune function [156], acidosis increases the release and production of plasminogen activator inhibitor 1 (PAI-1) by the mesothelial cells [157] and up-regulates vascular endothelial growth factor (VEGF) expression independently from hypoxia [158], which has been reported to be involved in adhesion formation [159-163].

Moreover, the effect of other gases has been studied with regard to adhesions. It was demonstrated that helium-induced pneumoperitoneum caused the same quantity of adhesions to that of $\mathrm{CO}_{2}$-induced pneumoperitoneum [146] and that adding 5-10\% of $\mathrm{N}_{2} \mathrm{O}$ to the $\mathrm{CO}_{2}$-induced pneumoperitoneum significantly reduced post-operative adhesions [164]. The exact effect of $\mathrm{N}_{2} \mathrm{O}$ upon post-operative adhesions cannot be explained by the current knowledge. It was hypothesised that $\mathrm{N}_{2} \mathrm{O}$ may be reducing the acute inflammation at the peritoneal cavity in comparison with that evident in $\mathrm{CO}_{2}$-induced pneumoperitoneum.

It has been claimed that the desiccation caused by the standard dry and cold $\mathrm{CO}_{2}$ pneumoperitoneum will favour the development of post-operative adhesions. In vitro studies confirm that the degree of desiccation depends on the flow rate of the gas through the humidified surface. Indeed, when dry and cold $\mathrm{CO}_{2}$ circulates through waterfilled flasks, the water lost depends on the flow rate; the higher the flow, the more desiccation is observed [148]. The effect of dry $\mathrm{CO}_{2}$ with different insufflation pressures and flow rates through the abdominal cavity upon adhesion formation was evaluated, showing that adhesion formation increased with higher insufflation pressures and with higher flow rates [26, 148, 150]. Furthermore, this desiccationinduced adhesion formation was reduced using warm and humidified gas in mice [26] and in rats [64]. Therefore, the key role of desiccation in the pathogenesis of the adhesion formation is evident. The hypothesis of desiccation as a driving mechanism in adhesion formation is supported by the data demonstrating that the dry and cold $\mathrm{CO}_{2}$-induced pneumoperitoneum alters the morphology of the mesothelium as explained in detail previously [27, 64, 65, 104, 105], which can favour the development of post-operative adhesions.

The effect of using humidified insufflation gas to reduce adhesions is clear. Therefore, the effect of using humidified gas at different temperatures was also studied showing that hypothermia reduced adhesion formation in mice [26, 165]. Consistent with these results, animal data demonstrated that peritoneal infusion with cold saline at $4{ }^{\circ} \mathrm{C}$ decreased post-operative adhesions [166], whereas irrigation with saline at warmer than body temperature increased postoperative adhesions [167]. Recent experiments confirmed that peritoneal infusion with cold saline at $4{ }^{\circ} \mathrm{C}$ decreased post-operative adhesions and same results were obtained using cold saline at 10 and $15{ }^{\circ} \mathrm{C}$ [168]. Several mechanisms might be involved in this beneficial effect of hypothermia. Adhesion formation might be reduced by hypothermia through protecting tissues and cells from the pneumoperitoneum-induced hypoxia, since cell oxygen consumption decreases with temperature. Indeed, hypothermia decreases the global cerebral metabolic rate during ischaemia, slowing the breakdown of glucose, phosphocreatine and adenosine triphosphate (ATP) and the formation of lactate and inorganic phosphate [169]. In addition, hypothermia reduces the production of ROS during reperfusion [170-172], improves the recovery of energetic parameters during reperfusion [169], and suppresses the inflammatory response thus decreasing the infiltration of polymorphonuclear (PMN) cells and the production of TNF- $\alpha$, interleukin $1 \beta$ (IL1 $\beta$ ) and macrophage inflammatory protein-2 [173, 174]. In the recent article of Lin et al. [168], intra-peritoneal cold infusion at 4, 10 and $15^{\circ} \mathrm{C}$ has shown a decrease of post-operative adhesions together with a decrease of the levels of TNF- $\alpha$ and interleukin 6 (IL6) compared with those in the group without saline infusion.

These results were further translated to clinical trials showing that it is possible to insufflate humidified and cold gas $\left(32{ }^{\circ} \mathrm{C}, 100 \% \mathrm{RH}\right)$ reducing the abdominal temperature locally but without affecting the core body temperature [66]. In an RCT in deep endometriosis surgery [85], post-operative adhesions were completely prevented in 12 out of 16 women using full-conditioning (86\% $\mathrm{CO}_{2}+10 \% \mathrm{~N}_{2} \mathrm{O}+4 \% \mathrm{O}_{2}$ for the pneumoperitoneum, humidification and cooling of the peritoneal cavity to $32{ }^{\circ} \mathrm{C}$ ), heparinised rinsing solution and $5 \mathrm{mg}$ of dexamethasone together with a barrier, whereas in the control group with humidified $\mathrm{CO}_{2}$ at $37{ }^{\circ} \mathrm{C}(n=11)$ all women had severe adhesions. Also the area, density and severity of adhesions were significantly less. In the control group, area, density and severity of adhesions were strongly interrelated suggesting a common enhancing factor. In the full-conditioning group, $\mathrm{CO}_{2}$ resorption, post-operative pain and CRP concentrations were lower while clinical recovery was faster and time to first flatus shorter.

In conclusion, animal data indicate that the standard dry and cold $\mathrm{CO}_{2}$-induced pneumoperitoneum is a cofactor in adhesion formation because it induces hypoxia, acidosis and desiccation. Peritoneal adhesions can be reduced to a 
large extent with adequate pneumoperitoneum conditioning i.e. by adding $3-4 \% \quad \mathrm{O}_{2}$ to avoid hypoxia, adding $5-10 \% \quad \mathrm{~N}_{2} \mathrm{O}$ to reduce (possibly) inflammation, humidifying the insufflation gas to avoid desiccation, and by slightly cooling the insufflation gas to reduce inflammation. The relevance of all these strategies for peritoneal environment conditioning, together with the application of a barrier and dexamethasone, was translated to humans to reduce adhesion formation [85]. This trial was a "first proof of concept" trial of adhesion formation in a limited number of patients and these results should be confirmed in other RCTs.

\section{Others: impact of the insufflation gas on the optical clarity}

When a cold object such as a laparoscope is introduced into a warm humid environment such as the abdomen, moisture in the environment condenses on the object, in this case the rigid laparoscope lens. If cool insufflation gas is continuously passing over the laparoscope during the course of an operation, it remains colder than the surrounding environment and it continues to fog up. Therefore, this imbalance between the temperature of the front lens of the laparoscope and that of the abdominal cavity will produce the laparoscopic lens fogging [175]. Lens fogging is a problem during laparoscopic surgery because a poor picture means that surgery must be stopped until the camera is cleaned and the picture stored, and may, therefore, contribute to surgical errors. Although this stoppage is rarely dangerous, it is frustrating for the surgeon and increases surgery time.

It is common practice to use anti-fogging solutions or devices such as a laparoscope warmer to prevent fogging. However, these methods fail to maintain the warm temperature at the front lens of the scope. Irrigation channels allow rinsing of the lens, but leave a residual liquid film layer which distorts the view [176]. Furthermore, when irrigation fluid is sprayed on the lens, if the fluid temperature is less than $37{ }^{\circ} \mathrm{C}$, it will cool the lens and thus contribute to subsequent fogging.

If the insufflation gas has been heated, the laparoscope will warm up and is less prone to fogging [176]. As long as humidified gas passing the laparoscope is slightly warmer than the dew point of the gas, there should be no condensation and hence no fogging on the lens. However, some studies demonstrated that lens fogging rates do not differ using humidified gas [13, 52, 53, 55]. Conversely, the median camera fogging score was significantly worse in the group in which humidified gas was used in a multicentre, double-blinded, randomised controlled study during laparoscopic colonic surgery [125].
In summary, although the aetiology of laparoscopic lens fogging is well understood, i.e. the temperature and humidity differences, the methods to reduce its occurrence lack significant data. Of those methods that are often espoused, most are not supported in the literature, such as warmed and humidified insufflation gas, or simply lack data, such as anti-fogging solutions [175].

\section{Conclusion}

The peritoneum, one of the largest organs in humans, has a very important function in the abdominal cavity, i.e. diminishes the friction, walls off infections and enables the secretion of cytokines. It is a very delicate layer highly susceptible to damage. Of course, it is not designed to cope with variable conditions such as being in contact with dry and cold air or $\mathrm{CO}_{2}$ during open and laparoscopic surgery, respectively. In this review, the effect of insufflating into the abdominal cavity with dry and cold $\mathrm{CO}_{2}$ was revised in detail.

Insufflating dry and cold $\mathrm{CO}_{2}$ into the abdominal cavity causes peritoneal damage, post-operative pain, hypothermia and post-operative adhesion formation. After the peritoneal trauma due to the desiccating nature of the dry gas, an inflammatory reaction is produced and peritoneal macrophages and lymphocytes will fill the gaps to recover the basal lamina. On the other hand, when humidified and heated $\mathrm{CO}_{2}$ is used, the peritoneal layer showed little change. Humidified and heated gas reduces the inflammatory response demonstrating that less trauma is incurred to the peritoneum. In addition, it has been clearly confirmed by clinical trials that warm and humidified gas prevents pain after surgery $[13,14]$.

Results related to patient recovery are still controversial. The recovery time is difficult to evaluate since it depends on several factors such as patient characteristics, surgeon skills, type of surgery and duration of the surgery.

With regard to hypothermia due to desiccation, it can be fully prevented using humidified and warm gas, as shown in animal models and in clinical trials [13]. A few studies using humidified and cold $\mathrm{CO}_{2}$ as insufflation gas have shown that the prevention of heat loss and desiccation associated with pneumoperitoneal insufflation are as effective as the use of warmed and humidified gas in animal models [62, 177] and in humans [66, 85]. This is consistent with the observation that much more energy is used to humidify a gas than to heat it up. Then, why use humidified and cold gas when the abdominal cavity's normal temperature is $37{ }^{\circ} \mathrm{C}$ ? The use of humidified and cold gas would produce locally hypothermia and may have many protecting effects against trauma. First, hypothermia suppresses the inflammatory response, decreasing the 
infiltration of PMN cells, and the production of TNF- $\alpha$, IL$1 \beta$ and macrophage inflammatory protein-2 [168, 173, 174]. Second, hypothermia would directly protect tissues from the pneumoperitoneum-induced hypoxia, since oxygen consumption decreases with temperature. Third, hypothermia reduces the production of ROS during reperfusion in several organs [170-172, 178-180]. Fourth, hypothermia improves recovery of energetic parameters during reperfusion [169]. Last and not least, hypothermia decreases post-operative adhesions in animal models [26, $165,166,168]$ and this can easily be translated to humans by inducing a local hypothermia of $32{ }^{\circ} \mathrm{C}$ [66].

In summary, using humidified and warm insufflation gas now offers a significant clinical benefit to the patient, creating a more physiologic peritoneal environment and reducing the post-operative pain and hypothermia. Moreover, although humidified and warm gas reduces post-operative adhesions in animal models, humidified gas at $32{ }^{\circ} \mathrm{C}$ decreased it even more. It is clear that humidified gas should be used during laparoscopic surgery; however, a question remains unanswered: to achieve even greater clinical benefit to the patient, at what temperature should the humidified gas be when insufflated into the abdomen? More clinical trials should be performed to resolve this query.

Acknowledgments Nicolò Giacomuzzi-Moore is acknowledged for revising the manuscript.

Conflict of interest MM Binda was consultant for Fisher and Paykel Healthcare, Auckland, New Zealand. The review design and conclusions were independently designed and drafted by the author.

Open Access This article is distributed under the terms of the Creative Commons Attribution 4.0 International License (http:// creativecommons.org/licenses/by/4.0/), which permits unrestricted use, distribution, and reproduction in any medium, provided you give appropriate credit to the original author(s) and the source, provide a link to the Creative Commons license, and indicate if changes were made.

\section{References}

1. Slater NJ, Raftery AT, Cope GH (1989) The ultrastructure of human abdominal mesothelium. J Anat 167:47-56

2. Albanese AM, Albanese EF, Mino JH, Gomez E, Gomez M, Zandomeni M, Merlo AB (2009) Peritoneal surface area: measurements of 40 structures covered by peritoneum: correlation between total peritoneal surface area and the surface calculated by formulas. Surg Radiol Anat 31:369-377

3. diZerega GS (1997) Biochemical events in peritoneal tissue repair. Eur J Surg Suppl 577:10-16

4. Mutsaers SE (2004) The mesothelial cell. Int J Biochem Cell Biol 36:9-16

5. Yung S, Chan TM (2007) Mesothelial cells. Perit Dial Int 27(Suppl 2):S110-S115

6. Collet D, Vitale GC, Reynolds M, Klar E, Cheadle WG (1995) Peritoneal host defenses are less impaired by laparoscopy than by open operation. Surg Endosc 9:1059-1064
7. Allendorf JD, Bessler M, Whelan RL, Trokel M, Laird DA, Terry MB, Treat MR (1997) Postoperative immune function varies inversely with the degree of surgical trauma in a murine model. Surg Endosc 11:427-430

8. Sajid MS, Bokhari SA, Mallick AS, Cheek E, Baig MK (2009) Laparoscopic versus open repair of incisional/ventral hernia: a meta-analysis. Am J Surg 197:64-72

9. Sauerland S, Lefering R, Neugebauer EA (2004) Laparoscopic versus open surgery for suspected appendicitis. Cochrane Database Syst Rev 18(4):CD001546

10. Chung RS, Rowland DY, Li P, Diaz J (1999) A meta-analysis of randomized controlled trials of laparoscopic versus conventional appendectomy. Am J Surg 177:250-256

11. Karthikesalingam A, Markar SR, Holt PJ, Praseedom RK (2010) Meta-analysis of randomized controlled trials comparing laparoscopic with open mesh repair of recurrent inguinal hernia. Br J Surg 97:4-11

12. Neuhaus SJ, Gupta A, Watson DI (2001) Helium and other alternative insufflation gases for laparoscopy. Surg Endosc 15:553-560

13. Sajid MS, Mallick AS, Rimpel J, Bokari SA, Cheek E, Baig MK (2008) Effect of heated and humidified carbon dioxide on patients after laparoscopic procedures: a meta-analysis. Surg Laparosc Endosc Percutan Tech 18:539-546

14. Sammour T, Kahokehr A, Hill AG (2008) Meta-analysis of the effect of warm humidified insufflation on pain after laparoscopy. Br J Surg 95:950-956

15. Dellon ES, Hawk JS, Grimm IS, Shaheen NJ (2009) The use of carbon dioxide for insufflation during GI endoscopy: a systematic review. Gastrointest Endosc 69:843-849

16. Mouton WG, Naef M, Bessell JR, Otten KT, Wagner HE, Maddern GJ (2001) A randomized controlled trial to determine the effect of humidified carbon dioxide $\left(\mathrm{CO}_{2}\right)$ insufflation on postoperative pain following thoracoscopic procedures. Surg Endosc 15:579-581

17. Yamano HO, Yoshikawa K, Kimura T, Yamamoto E, Harada E, Kudou T, Katou R, Hayashi Y, Satou K (2010) Carbon dioxide insufflation for colonoscopy: evaluation of gas volume, abdominal pain, examination time and transcutaneous partial $\mathrm{CO}(2)$ pressure. J Gastroenterol 45(12):1235-1240

18. Brusco GF, Arena S, Angelini A (2003) Use of carbon dioxide versus normal saline for diagnostic hysteroscopy. Fertil Steril 79:993-997

19. Persson M, van der Linden J (2009) Intraoperative field flooding with warm humidified $\mathrm{CO}_{2}$ may help to prevent adhesion formation after open surgery. Med Hypotheses 73:521-523

20. Frey JM, Janson M, Svanfeldt M, Svenarud PK, van der Linden JA (2012) Local insufflation of warm humidified CO(2)increases open wound and core temperature during open colon surgery: a randomized clinical trial. Anesth Analg 115:1204 1211

21. Frey JM, Janson M, Svanfeldt M, Svenarud PK, van der Linden JA (2012) Intraoperative local insufflation of warmed humidified $\mathrm{CO}(2)$ increases open wound and core temperatures: a randomized clinical trial. World J Surg 36:2567-2575

22. Frey JM, Svegby HK, Svenarud PK, van der Linden JA (2010) $\mathrm{CO}_{2}$ insufflation influences the temperature of the open surgical wound. Wound Repair Regen 18:378-382

23. Corona R (2011) The role of the entire peritoneal cavity in postoperative adhesion formation: from the laboratory to the operating theatre. PhD Dissertation, Catholic University of Leuven, Leuven, Belgium. https://lirias.kuleuven.be/bitstream/123456789/ 314777/1/THESIS_total.pdf

24. Bessell JR, Karatassas A, Patterson JR, Jamieson GG, Maddern GJ (1995) Hypothermia induced by laparoscopic insufflation. A randomized study in a pig model. Surg Endosc 9:791-796 
25. Bessell JR, Ludbrook G, Millard SH, Baxter PS, Ubhi SS, Maddern GJ (1999) Humidified gas prevents hypothermia induced by laparoscopic insufflation: a randomized controlled study in a pig model. Surg Endosc 13:101-105

26. Binda MM, Molinas CR, Hansen P, Koninckx PR (2006) Effect of desiccation and temperature during laparoscopy on adhesion formation in mice. Fertil Steril 86:166-175

27. Hazebroek EJ, Schreve MA, Visser P, De Bruin RW, Marquet RL, Bonjer HJ (2002) Impact of temperature and humidity of carbon dioxide pneumoperitoneum on body temperature and peritoneal morphology. J Laparoendosc Adv Surg Tech A $12: 355-364$

28. Ott DE (1991) Correction of laparoscopic insufflation hypothermia. J Laparoendosc Surg 1:183-186

29. Ott DE (1991) Laparoscopic hypothermia. J Laparoendosc Surg $1: 127-131$

30. Gray RI, Ott DE, Henderson AC, Cochran SA, Roth EA (1999) Severe local hypothermia from laparoscopic gas evaporative jet cooling: a mechanism to explain clinical observations. JSLS 3:171-177

31. Mynbaev OA, Molinas CR, Adamyan LV, Vanacker B, Koninckx PR (2002) Pathogenesis of $\mathrm{CO}(2)$ pneumoperitoneuminduced metabolic hypoxemia in a rabbit model. J Am Assoc Gynecol Laparosc 9:306-314

32. Molinas CR, Tjwa M, Vanacker B, Binda MM, Elkelani O, Koninckx PR (2004) Role of CO(2) pneumoperitoneum-induced acidosis in $\mathrm{CO}(2)$ pneumoperitoneum-enhanced adhesion formation in mice. Fertil Steril 81:708-711

33. Junghans T, Bohm B, Grundel K, Schwenk W (1997) Effects of pneumoperitoneum with carbon dioxide, argon, or helium on hemodynamic and respiratory function. Arch Surg 132:272-278

34. Liem TK, Krishnamoorthy M, Applebaum H, Kolata R, Rudd RG, Chen W (1996) A comparison of the hemodynamic and ventilatory effects of abdominal insufflation with helium and carbon dioxide in young swine. J Pediatr Surg 31:297-300

35. Volz J, Koster S, Weiss M, Schmidt R, Urbaschek R, Melchert F, Albrecht M (1996) Pathophysiologic features of a pneumoperitoneum at laparoscopy: a swine model. Am J Obstet Gynecol 174:132-140

36. Neuberger TJ, Andrus CH, Wittgen CM, Wade TP, Kaminski DL (1996) Prospective comparison of helium versus carbon dioxide pneumoperitoneum. Gastrointest Endosc 43:38-41

37. Horvath KD, Whelan RL, Lier B, Viscomi S, Barry L, Buck K, Bessler M (1998) The effects of elevated intraabdominal pressure, hypercarbia, and positioning on the hemodynamic responses to laparoscopic colectomy in pigs. Surg Endosc $12: 107-114$

38. Sammour T, Mittal A, Loveday BP, Kahokehr A, Phillips AR, Windsor JA, Hill AG (2009) Systematic review of oxidative stress associated with pneumoperitoneum. Br J Surg 96:836-850

39. Helvacioglu A, Weis R (1992) Operative laparoscopy and postoperative pain relief. Fertil Steril 57:548-552

40. Ott DE (2001) Laparoscopy and tribology: the effect of laparoscopic gas on peritoneal fluid. J Am Assoc Gynecol Laparose 8:117-123

41. Neuhaus SJ, Watson DI (2004) Pneumoperitoneum and peritoneal surface changes: a review. Surg Endosc 18:1316-1322

42. Taskin O, Buhur A, Birincioglu M, Burak F, Atmaca R, Yilmaz I, Wheeler JM (1998) The effects of duration of $\mathrm{CO}_{2}$ insufflation and irrigation on peritoneal microcirculation assessed by free radical scavengers and total glutathion levels during operative laparoscopy. J Am Assoc Gynecol Laparosc 5:129-133

43. Brokelman WJ, Lensvelt M, Rinkes IH, Klinkenbijl JH, Reijnen MM (2010) Peritoneal changes due to laparoscopic surgery. Surg Endosc 25(1):1-9
44. Kurz A (2008) Physiology of thermoregulation. Best Pract Res Clin Anaesthesiol 22:627-644

45. Kurz A, Sessler DI, Narzt E, Lenhardt R, Lackner F (1995) Morphometric influences on intraoperative core temperature changes. Anesth Analg 80:562-567

46. Rosenthal RJ, Friedman RL, Phillips EH (1998) The pathophysiology of pneumoperitoneum. In: Bessell JR, Maddern GJ (eds) Influence of gas temperature during laparoscopic procedures. Springer, Heidelberg, pp 18-27

47. Buhre W, Rossaint R (2003) Perioperative management and monitoring in anaesthesia. Lancet 362:1839-1846

48. Sessler DI (2001) Complications and treatment of mild hypothermia. Anesthesiology 95:531-543

49. Margulis V, Matsumoto ED, Tunc L, Taylor G, Duchenne D, Cadeddu JA (2005) Effect of warmed, humidified insufflation gas and anti-inflammatory agents on cytokine response to laparoscopic nephrectomy: porcine model. J Urol 174:1452-1456

50. Ott DE, Reich H, Love B, McCorvey R, Toledo A, Liu CY, Syed R, Kumar K (1998) Reduction of laparoscopic-induced hypothermia, postoperative pain and recovery room length of stay by pre-conditioning gas with the Insuflow device: a prospective randomized controlled multi-center study. JSLS 2:321-329

51. Mouton WG, Bessell JR, Millard SH, Baxter PS, Maddern GJ (1999) A randomized controlled trial assessing the benefit of humidified insufflation gas during laparoscopic surgery. Surg Endosc 13:106-108

52. Nguyen NT, Furdui G, Fleming NW, Lee SJ, Goldman CD, Singh A, Wolfe BM (2002) Effect of heated and humidified carbon dioxide gas on core temperature and postoperative pain: a randomized trial. Surg Endosc 16:1050-1054

53. Farley DR, Greenlee SM, Larson DR, Harrington JR (2004) Double-blind, prospective, randomized study of warmed, humidified carbon dioxide insufflation vs standard carbon dioxide for patients undergoing laparoscopic cholecystectomy. Arch Surg 139:739-743

54. Savel RH, Balasubramanya S, Lasheen S, Gaprindashvili T, Arabov E, Fazylov RM, Lazzaro RS, Macura JM (2005) Beneficial effects of humidified, warmed carbon dioxide insufflation during laparoscopic bariatric surgery: a randomized clinical trial. Obes Surg 15:64-69

55. Hamza MA, Schneider BE, White PF, Recart A, Villegas L, Ogunnaike B, Provost D, Jones D (2005) Heated and humidified insufflation during laparoscopic gastric bypass surgery: effect on temperature, postoperative pain, and recovery outcomes. J Laparoendosc Adv Surg Tech A 15:6-12

56. Backlund M, Kellokumpu I, Scheinin T, von SK, Tikkanen I, Lindgren L (1998) Effect of temperature of insufflated $\mathrm{CO}_{2}$ during and after prolonged laparoscopic surgery. Surg Endosc 12:1126-1130

57. Puttick MI, Scott-Coombes DM, Dye J, Nduka CC, MenziesGow NM, Mansfield AO, Darzi A (1999) Comparison of immunologic and physiologic effects of $\mathrm{CO}_{2}$ pneumoperitoneum at room and body temperatures. Surg Endosc 13:572-575

58. Saad S, Minor I, Mohri T, Nagelschmidt M (2000) The clinical impact of warmed insufflation carbon dioxide gas for laparoscopic cholecystectomy. Surg Endosc 14:787-790

59. Slim K, Bousquet J, Kwiatkowski F, Lescure G, Pezet D, Chipponi J (1999) Effect of $\mathrm{CO}(2)$ gas warming on pain after laparoscopic surgery: a randomized double-blind controlled trial. Surg Endosc 13:1110-1114

60. Nelskyla K, Yli-Hankala A, Sjoberg J, Korhonen I, Korttila K (1999) Warming of insufflation gas during laparoscopic hysterectomy: effect on body temperature and the autonomic nervous system. Acta Anaesthesiol Scand 43:974-978

61. Davis SS, Mikami DJ, Newlin M, Needleman BJ, Barrett MS, Fries R, Larson T, Dundon J, Goldblatt MI, Melvin WS (2006) 
Heating and humidifying of carbon dioxide during pneumoperitoneum is not indicated: a prospective randomized trial. Surg Endosc 20:153-158

62. Schlotterbeck H, Schaeffer R, Dow WA, Diemunsch P (2008) Cold nebulization used to prevent heat loss during laparoscopic surgery: an experimental study in pigs. Surg Endosc 22:2616-2620

63. Noll E, Schaeffer R, Joshi G, Diemunsch S, Koessler S, Diemunsch P (2012) Heat loss during carbon dioxide insufflation: comparison of a nebulization based humidification device with a humidification and heating system. Surg Endosc 26:3622-3625

64. Peng Y, Zheng M, Ye Q, Chen X, Yu B, Liu B (2009) Heated and humidified $\mathrm{CO}_{2}$ prevents hypothermia, peritoneal injury, and intra-abdominal adhesions during prolonged laparoscopic insufflations. J Surg Res 151:40-47

65. Mouton WG, Bessell JR, Pfitzner J, Dymock RB, Brealey J, Maddern GJ (1999) A randomized controlled trial to determine the effects of humidified carbon dioxide insufflation during thoracoscopy. Surg Endosc 13:382-385

66. Corona R, Verguts J, Koninckx R, Mailova K, Binda MM, Koninckx PR (2011) Intraperitoneal temperature and desiccation during endoscopic surgery. Intraoperative humidification and cooling of the peritoneal cavity can reduce adhesions. Am J Obstet Gynecol 205:392-397

67. Huntington TR, LeMaster CB (1997) Laparoscopic hypothermia: heat loss from insufflation gas flow. Surg Laparosc Endosc $7: 153-155$

68. Wills VL, Hunt DR, Armstrong A (2001) A randomized controlled trial assessing the effect of heated carbon dioxide for insufflation on pain and recovery after laparoscopic fundoplication. Surg Endosc 15:166-170

69. Neudecker J, Sauerland S, Neugebauer E, Bergamaschi R, Bonjer HJ, Cuschieri A, Fuchs KH, Jacobi C, Jansen FW, Koivusalo AM, Lacy A, McMahon MJ, Millat B, Schwenk W (2002) The European Association for Endoscopic Surgery clinical practice guideline on the pneumoperitoneum for laparoscopic surgery. Surg Endosc 16:1121-1143

70. Neugebauer EAM, Sauerland S, Fingerhut A, Millat B, Buess G (2006) EAES guidelines for endoscopic surgery. Twelve years evidence-based surgery in Europe. Springer, Heidelberg

71. Meaume S, Teot L, Lazareth I, Martini J, Bohbot S (2004) The importance of pain reduction through dressing selection in routine wound management: the MAPP study. J Wound Care 13:409-413

72. Arroyo-Novoa CM, Figueroa-Ramos MI, Miaskowski C, Padilla G, Stotts N, Puntillo KA (2009) Acute wound pain: gaining a better understanding. Adv Skin Wound Care 22:373-380

73. Ortega AE, Hunter JG, Peters JH, Swanstrom LL, Schirmer B (1995) A prospective, randomized comparison of laparoscopic appendectomy with open appendectomy. Laparoscopic Appendectomy Study Group. Am J Surg 169:208-212

74. Mouton WG, Bessell JR, Otten KT, Maddern GJ (1999) Pain after laparoscopy. Surg Endosc 13:445-448

75. Wills VL, Hunt DR (2000) Pain after laparoscopic cholecystectomy. Br J Surg 87:273-284

76. Menes T, Spivak H (2000) Laparoscopy: searching for the proper insufflation gas. Surg Endosc 14:1050-1056

77. Hunter JG, Staheli J, Oddsdottir M, Trus T (1995) Nitrous oxide pneumoperitoneum revisited. Is there a risk of combustion? Surg Endosc 9:501-504

78. Cheng Y, Lu J, Xiong X, Wu S, Lin Y, Wu T, Cheng N (2013) Gases for establishing pneumoperitoneum during laparoscopic abdominal surgery. Cochrane Database Syst Rev 31(1):CD009569

79. El-Kady AA, Abd-El-Razek M (1976) Intraperitoneal explosion during female sterilization by laparoscopic electrocoagulation. A case report. Int J Gynaecol Obstet 14:487-488
80. Gunatilake DE (1978) Case report: fatal intraperitoneal explosion during electrocoagulation via laparoscopy. Int J Gynaecol Obstet 15:353-357

81. Neuman GG, Sidebotham G, Negoianu E, Bernstein J, Kopman AF, Hicks RG, West ST, Haring L (1993) Laparoscopy explosion hazards with nitrous oxide. Anesthesiology 78:875-879

82. Aitola P, Airo I, Kaukinen S, Ylitalo P (1998) Comparison of $\mathrm{N}_{2} \mathrm{O}$ and $\mathrm{CO}_{2}$ pneumoperitoneums during laparoscopic cholecystectomy with special reference to postoperative pain. Surg Laparosc Endosc 8:140-144

83. Rammohan A, Manimaran AB, Manohar RR, Naidu RM (2010) Nitrous oxide for pneumoperitoneum: no laughing matter this! A prospective single blind case controlled study. Int J Surg $9(2): 173-176$

84. Tsereteli Z, Terry ML, Bowers SP, Spivak H, Archer SB, Galloway KD, Hunter JG (2002) Prospective randomized clinical trial comparing nitrous oxide and carbon dioxide pneumoperitoneum for laparoscopic surgery. J Am Coll Surg 195:173-179

85. Koninckx PR, Corona R, Timmerman D, Verguts J, Adamyan L (2013) Peritoneal full-conditioning reduces postoperative adhesions and pain: a randomised controlled trial in deep endometriosis surgery. J Ovarian Res 6:90

86. O'Boyle CJ, DeBeaux AC, Watson DI, Ackroyd R, Lafullarde T, Leong JY, Williams JA, Jamieson GG (2002) Helium vs carbon dioxide gas insufflation with or without saline lavage during laparoscopy. Surg Endosc 16:620-625

87. Tsimoyiannis EC, Siakas P, Tassis A, Lekkas ET, Tzourou H, Kambili M (1998) Intraperitoneal normal saline infusion for postoperative pain after laparoscopic cholecystectomy. World $\mathbf{J}$ Surg 22:824-828

88. Jackson SA, Laurence AS, Hill JC (1996) Does post-laparoscopy pain relate to residual carbon dioxide? Anaesthesia $51: 485-487$

89. Fredman B, Jedeikin R, Olsfanger D, Flor P, Gruzman A (1994) Residual pneumoperitoneum: a cause of postoperative pain after laparoscopic cholecystectomy. Anesth Analg 79:152-154

90. Abbott J, Hawe J, Srivastava P, Hunter D, Garry R (2001) Intraperitoneal gas drain to reduce pain after laparoscopy: randomized masked trial. Obstet Gynecol 98:97-100

91. Swift G, Healey M, Varol N, Maher P, Hill D (2002) A prospective randomised double-blind placebo controlled trial to assess whether gas drains reduce shoulder pain following gynaecological laparoscopy. Aust N Z J Obstet Gynaecol 42:267-270

92. Tzovaras G, Liakou P, Fafoulakis F, Baloyiannis I, Zacharoulis D, Hatzitheofilou C (2009) Is there a role for drain use in elective laparoscopic cholecystectomy? A controlled randomized trial. Am J Surg 197:759-763

93. Gurusamy KS, Samraj K, Mullerat P, Davidson BR (2007) Routine abdominal drainage for uncomplicated laparoscopic cholecystectomy. Cochrane Database Syst Rev CD006004

94. Glew PA, Campher MJ, Pearson K, Schofield JC, Davey AK (2004) The effect of warm humidified $\mathrm{CO}_{2}$ on the dissipation of residual gas following laparoscopy in piglets. J Am Assoc Gynecol Laparosc 11:204-210

95. Alexander JI, Hull MG (1987) Abdominal pain after laparoscopy: the value of a gas drain. Br J Obstet Gynaecol 94:267-269

96. Kissler S, Haas M, Strohmeier R, Schmitt H, Rody A, Kaufmann $\mathrm{M}$, Siebzehnruebl E (2004) Effect of humidified and heated $\mathrm{CO}_{2}$ during gynecologic laparoscopic surgery on analgesic requirements and postoperative pain. J Am Assoc Gynecol Laparosc $11: 473-477$

97. Korell M, Schmaus F, Strowitzki T, Schneeweiss SG, Hepp H (1996) Pain intensity following laparoscopy. Surg Laparosc Endosc 6:375-379 
98. Benavides R, Wong A, Nguyen H (2009) Improved outcomes for lap-banding using the Insuflow device compared with heated-only gas. JSLS 13:302-305

99. Demco L (2001) Effect of heating and humidifying gas on patients undergoing awake laparoscopy. J Am Assoc Gynecol Laparose 8:247-251

100. Almeida OD Jr (2002) Awake microlaparoscopy with the Insuflow device. JSLS 6:199-201

101. Champion JK, Williams M (2006) Prospective randomized trial of heated humidified versus cold dry carbon dioxide insufflation during laparoscopic gastric bypass. Surg Obes Relat Dis 2:445-449

102. Yu TC, Hamill JK, Liley A, Hill AG (2013) Warm, humidified carbon dioxide gas insufflation for laparoscopic appendicectomy in children: a double-blinded randomized controlled trial. Ann Surg 257:44-53

103. Erikoglu M, Yol S, Avunduk MC, Erdemli E, Can A (2005) Electron-microscopic alterations of the peritoneum after both cold and heated carbon dioxide pneumoperitoneum. J Surg Res 125:73-77

104. Volz J, Koster S, Spacek Z, Paweletz N (1999) Characteristic alterations of the peritoneum after carbon dioxide pneumoperitoneum. Surg Endosc 13:611-614

105. Suematsu T, Hirabayashi Y, Shiraishi N, Adachi Y, Kitamura H, Kitano S (2001) Morphology of the murine peritoneum after pneumoperitoneum vs laparotomy. Surg Endosc 15:954-958

106. Rosario MT, Ribeiro U Jr, Corbett CE, Ozaki AC, Bresciani CC, Zilberstein B, Gama-Rodrigues JJ (2006) Does $\mathrm{CO}_{2}$ pneumoperitoneum alter the ultra-structure of the mesothelium? J Surg Res 133:84-88

107. Liu Y, Hou QX (2006) Effect of carbon dioxide pneumoperitoneum during laparoscopic surgery on morphology of peritoneum. Zhonghua Yi Xue Za Zhi 86:164-166

108. Papparella A, Nino F, Coppola S, Noviello C, Paciello O, Papparella S (2013) Peritoneal morphological changes due to pneumoperitoneum: the effect of intra-abdominal pressure. Eur J Pediatr Surg 24(4):322-327

109. de CJ, Wilson E (2007) Heating and humidifying carbon dioxide is indicated. Surg Endosc 21:340-341

110. Pier A, Benedic M, Mann B, Buck V (1994) Postlaparoscopic pain syndrome. Results of a prospective, randomized study. Chirurg 65:200-208

111. Berberoglu M, Dilek ON, Ercan F, Kati I, Ozmen M (1998) The effect of $\mathrm{CO}_{2}$ insufflation rate on the postlaparoscopic shoulder pain. J Laparoendosc Adv Surg Tech A 8:273-277

112. Perry CP, Tombrello R (1993) Effect of fluid instillation on postlaparoscopy pain. J Reprod Med 38:768-770

113. Wallace DH, Serpell MG, Baxter JN, O'Dwyer PJ (1997) Randomized trial of different insufflation pressures for laparoscopic cholecystectomy. Br J Surg 84:455-458

114. Gurusamy KS, Samraj K, Davidson BR (2009) Low pressure versus standard pressure pneumoperitoneum in laparoscopic cholecystectomy. Cochrane Database Syst Rev 15(2):CD006930

115. Ryan GB, Grobety J, Majno G (1973) Mesothelial injury and recovery. Am J Pathol 71:93-112

116. Davey AK, Hayward J, Marshall JK, Woods AE (2013) The effects of insufflation conditions on rat mesothelium. Int J Inflam 2013:816283

117. Lackey LW, Ott DE (2002) Terminal gas velocity during laparoscopy. J Am Assoc Gynecol Laparosc 9:297-305

118. Ott DE (2003) Desertification of the peritoneum by thin-film evaporation during laparoscopy. JSLS 7:189-195

119. Papparella A, Noviello C, Romano M, Parmeggiani P, Paciello O, Papparella S (2007) Local and systemic impact of pneumoperitoneum on prepuberal rats. Pediatr Surg Int 23:453-457
120. Matsuzaki S, Jardon K, Maleysson E, D’Arpiany F, Canis M, Botchorishvili R (2012) Impact of intraperitoneal pressure of a $\mathrm{CO}_{2}$ pneumoperitoneum on the surgical peritoneal environment. Hum Reprod 27:1613-1623

121. Matsuzaki S, Jardon K, Maleysson E, D'Arpiany F, Canis M, Bazin JE, Mage G (2010) Carbon dioxide pneumoperitoneum, intraperitoneal pressure, and peritoneal tissue hypoxia: a mouse study with controlled respiratory support. Surg Endosc 24:2871-2880

122. Matsuzaki S, Botchorishvili R, Jardon K, Maleysson E, Canis M, Mage G (2011) Impact of intraperitoneal pressure and duration of surgery on levels of tissue plasminogen activator and plasminogen activator inhibitor-1 mRNA in peritoneal tissues during laparoscopic surgery. Hum Reprod 26:1073-1081

123. Corona R, Verguts J, Schonman R, Binda MM, Mailova K, Koninckx PR (2011) Postoperative inflammation in the abdominal cavity increases adhesion formation in a laparoscopic mouse model. Fertil Steril 95:1224-1228

124. Manwaring JM, Readman E, Maher PJ (2008) The effect of heated humidified carbon dioxide on postoperative pain, core temperature, and recovery times in patients having laparoscopic surgery: a randomized controlled trial. J Minim Invasive Gynecol 15:161-165

125. Sammour T, Kahokehr A, Hayes J, Hulme-Moir M, Hill AG (2010) Warming and humidification of insufflation carbon dioxide in laparoscopic colonic surgery: a double-blinded randomized controlled trial. Ann Surg 251:1024-1033

126. Diamond MP, Freeman ML (2001) Clinical implications of postsurgical adhesions. Hum Reprod Update 7:567-576

127. Ellis $H$ (1997) The clinical significance of adhesions: focus on intestinal obstruction. Eur J Surg Suppl 577:5-9

128. Menzies D, Ellis H (1990) Intestinal obstruction from adhesions-how big is the problem? Ann R Coll Surg Engl 72:60-63

129. Weibel MA, Majno G (1973) Peritoneal adhesions and their relation to abdominal surgery. A postmortem study. Am J Surg 126:345-353

130. Menzies D (1993) Postoperative adhesions: their treatment and relevance in clinical practice. Ann R Coll Surg Engl 75:147-153

131. Ellis H (1998) The magnitude of adhesion related problems. Ann Chir Gynaecol 87:9-11

132. Drake TS, Grunert GM (1980) The unsuspected pelvic factor in the infertility investigation. Fertil Steril 34:27-31

133. Hirschelmann A, Tchartchian G, Wallwiener M, Hackethal A, De Wilde RL (2012) A review of the problematic adhesion prophylaxis in gynaecological surgery. Arch Gynecol Obstet 285:1089-1097

134. Ray NF, Larsen JW Jr, Stillman RJ, Jacobs RJ (1993) Economic impact of hospitalizations for lower abdominal adhesiolysis in the United States in 1988. Surg Gynecol Obstet 176:271-276

135. Luciano AA, Maier DB, Koch EI, Nulsen JC, Whitman GF (1989) A comparative study of postoperative adhesions following laser surgery by laparoscopy versus laparotomy in the rabbit model. Obstet Gynecol 74:220-224

136. Garrard CL, Clements RH, Nanney L, Davidson JM, Richards WO (1999) Adhesion formation is reduced after laparoscopic surgery. Surg Endosc 13:10-13

137. Schippers E, Tittel A, Ottinger A, Schumpelick V (1998) Laparoscopy versus laparotomy: comparison of adhesion-formation after bowel resection in a canine model. Dig Surg 15:145-147

138. Schafer M, Krahenb hL, Buchler MW (1998) Comparison of adhesion formation in open and laparoscopic surgery. Dig Surg $15: 148-152$

139. Filmar S, Gomel V, McComb PF (1987) Operative laparoscopy versus open abdominal surgery: a comparative study on 
postoperative adhesion formation in the rat model. Fertil Steril 48:486-489

140. Jorgensen JO, Lalak NJ, Hunt DR (1995) Is laparoscopy associated with a lower rate of postoperative adhesions than laparotomy? A comparative study in the rabbit. Aust N Z J Surg 65:342-344

141. Marana R, Luciano AA, Muzii L, Marendino VE, Mancuso S (1994) Laparoscopy versus laparotomy for ovarian conservative surgery: a randomized trial in the rabbit model. Am J Obstet Gynecol 171:861-864

142. Lundorff P, Hahlin M, Kallfelt B, Thorburn J, Lindblom B (1991) Adhesion formation after laparoscopic surgery in tubal pregnancy: a randomized trial versus laparotomy. Fertil Steril 55:911-915

143. Bulletti C, Polli V, Negrini V, Giacomucci E, Flamigni C (1996) Adhesion formation after laparoscopic myomectomy. J Am Assoc Gynecol Laparosc 3:533-536

144. Pouly JL, Seak-San S (2000) Adhesions: laparoscopy versus laparotomy. In: diZerega GS (ed) Peritoneal surgery. Springer, New York, pp 183-192

145. Levrant SG, Bieber EJ, Barnes RB (1997) Anterior abdominal wall adhesions after laparotomy or laparoscopy. J Am Assoc Gynecol Laparosc 4:353-356

146. Molinas CR, Mynbaev O, Pauwels A, Novak P, Koninckx PR (2001) Peritoneal mesothelial hypoxia during pneumoperitoneum is a cofactor in adhesion formation in a laparoscopic mouse model. Fertil Steril 76:560-567

147. Molinas CR, Koninckx PR (2000) Hypoxaemia induced by $\mathrm{CO}(2)$ or helium pneumoperitoneum is a co-factor in adhesion formation in rabbits. Hum Reprod 15:1758-1763

148. Yesildaglar N, Ordonez JL, Laermans I, Koninckx PR (1999) The mouse as a model to study adhesion formation following endoscopic surgery: a preliminary report. Hum Reprod 14:55-59

149. Ordonez JL, Dominguez J, Evrard V, Koninckx PR (1997) The effect of training and duration of surgery on adhesion formation in the rabbit model. Hum Reprod 12:2654-2657

150. Yesildaglar N, Koninckx PR (2000) Adhesion formation in intubated rabbits increases with high insufflation pressure during endoscopic surgery. Hum Reprod 15:687-691

151. Guyton AC, Hall JE (2000) Transport of oxygen and carbon dioxide in the blood and body fluids. In: Guyton AC, Hall JE (eds) Textbook of medical physiology. WB Saunders, Philadelphia, pp 463-473

152. Elkelani OA, Binda MM, Molinas CR, Koninckx PR (2004) Effect of adding more than $3 \%$ oxygen to carbon dioxide pneumoperitoneum on adhesion formation in a laparoscopic mouse model. Fertil Steril 82:1616-1622

153. Wildbrett P, Oh A, Naundorf D, Volk T, Jacobi CA (2003) Impact of laparoscopic gases on peritoneal microenvironment and essential parameters of cell function. Surg Endosc 17:78-82

154. Matsuzaki S, Canis M, Bazin JE, Darcha C, Pouly JL, Mage G (2007) Effects of supplemental perioperative oxygen on post-operative abdominal wound adhesions in a mouse laparotomy model with controlled respiratory support. Hum Reprod 22:2702-2706

155. Kotzampassi K, Kapanidis N, Kazamias P, Eleftheriadis E (1993) Hemodynamic events in the peritoneal environment during pneumoperitoneum in dogs. Surg Endosc 7:494-499

156. Lardner A (2001) The effects of extracellular $\mathrm{pH}$ on immune function. J Leukoc Biol 69:522-530

157. Bergstrom M, Falk P, Holmdahl L (2006) Effect of acidosis on expression of mesothelial cell plasminogen activator inhibitor type-1. Surg Endosc 20:1448-1452

158. Fukumura D, Xu L, Chen Y, Gohongi T, Seed B, Jain RK (2001) Hypoxia and acidosis independently up-regulate vascular endothelial growth factor transcription in brain tumors in vivo. Cancer Res 61:6020-6024
159. Molinas CR, Binda MM, Carmeliet P, Koninckx PR (2004) Role of vascular endothelial growth factor receptor 1 in basal adhesion formation and in carbon dioxide pneumoperitoneum-enhanced adhesion formation after laparoscopic surgery in mice. Fertil Steril 82(Suppl 3):1149-1153

160. Molinas CR, Campo R, Elkelani OA, Binda MM, Carmeliet P, Koninckx PR (2003) Role of hypoxia inducible factors 1alpha and 2alpha in basal adhesion formation and in carbon dioxide pneumoperitoneum-enhanced adhesion formation after laparoscopic surgery in transgenic mice. Fertil Steril 80(Suppl 2):795-802

161. Rout UK, Oommen K, Diamond MP (2000) Altered expressions of VEGF mRNA splice variants during progression of uterineperitoneal adhesions in the rat. Am J Reprod Immunol 43:299-304

162. Saltzman AK, Olson TA, Mohanraj D, Carson LF, Ramakrishnan S (1996) Prevention of postoperative adhesions by an antibody to vascular permeability factor/vascular endothelial growth factor in a murine model. Am J Obstet Gynecol 174:1502-1506

163. Wiczyk HP, Grow DR, Adams LA, O'Shea DL, Reece MT (1998) Pelvic adhesions contain sex steroid receptors and produce angiogenesis growth factors. Fertil Steril 69:511-516

164. Corona R, Binda MM, Mailova K, Verguts J, Koninckx PR (2013) Addition of nitrous oxide to the carbon dioxide pneumoperitoneum strongly decreases adhesion formation and the dose-dependent adhesiogenic effect of blood in a laparoscopic mouse model. Fertil Steril 100:1777-1783

165. Binda MM, Molinas CR, Mailova K, Koninckx PR (2004) Effect of temperature upon adhesion formation in a laparoscopic mouse model. Hum Reprod 19:2626-2632

166. Fang CC, Chou TH, Lin GS, Yen ZS, Lee CC, Chen SC (2010) Peritoneal infusion with cold saline decreased postoperative intra-abdominal adhesion formation. World J Surg 34:721-727

167. Kappas AM, Fatouros M, Papadimitriou K, Katsouyannopoulos V, Cassioumis D (1988) Effect of intraperitoneal saline irrigation at different temperatures on adhesion formation. Br J Surg 75:854-856

168. Lin HF, Wu CY, Wu MC, Chou TH, Lin GS, Yen ZS, Chen SC (2014) Hypothermia decreases postoperative intra-abdominal adhesion formation. Am J Surg 208(3):419-424

169. Erecinska M, Thoresen M, Silver IA (2003) Effects of hypothermia on energy metabolism in Mammalian central nervous system. J Cereb Blood Flow Metab 23:513-530

170. Horiguchi T, Shimizu K, Ogino M, Suga S, Inamasu J, Kawase $\mathrm{T}$ (2003) Postischemic hypothermia inhibits the generation of hydroxyl radical following transient forebrain ischemia in rats. J Neurotrauma 20:511-520

171. Prasad MR, Liu X, Rousou JA, Engelman RM, Jones R, George A, Das DK (1992) Reduced free radical generation during reperfusion of hypothermically arrested hearts. Mol Cell Biochem 111:97-102

172. Zhao W, Richardson JS, Mombourquette MJ, Weil JA, Ijaz S, Shuaib A (1996) Neuroprotective effects of hypothermia and $\mathrm{U}-78517 \mathrm{~F}$ in cerebral ischemia are due to reducing oxygenbased free radicals: an electron paramagnetic resonance study with gerbils. J Neurosci Res 45:282-288

173. Kato A, Singh S, McLeish KR, Edwards MJ, Lentsch AB (2002) Mechanisms of hypothermic protection against ischemic liver injury in mice. Am $\mathrm{J}$ Physiol Gastrointest Liver Physiol 282:G608-G616

174. Patel S, Pachter HL, Yee H, Schwartz JD, Marcus SG, Shamamian P (2000) Topical hepatic hypothermia attenuates pulmonary injury after hepatic ischemia and reperfusion. J Am Coll Surg 191:650-656

175. Lawrentschuk N, Fleshner NE, Bolton DM (2010) Laparoscopic lens fogging: a review of etiology and methods to maintain a clear visual field. J Endourol 24:905-913 
176. Bessell JR, Flemming E, Kunert W, Buess G (1996) Maintenance of clear vision during laparoscopic surgery. Minim Invasive Ther Allied Technol 5:450-455

177. Schlotterbeck H, Greib N, Dow WA, Schaeffer R, Geny B, Diemunsch PA (2011) Changes in core temperature during peritoneal insufflation: comparison of two $\mathrm{CO}_{2}$ humidification devices in pigs. J Surg Res 171:427-432

178. Attuwaybi BO, Hassoun HT, Zou L, Kozar RA, Kone BC, Weisbrodt NW, Moore FA (2003) Hypothermia protects against gut ischemia/reperfusion-induced impaired intestinal transit by inducing heme oxygenase-1. J Surg Res 115:48-55

179. Zar HA, Lancaster JR Jr (2000) Mild hypothermia protects against postischemic hepatic endothelial injury and decreases the formation of reactive oxygen species. Redox Rep 5:303-310

180. Yoshioka T, Shires GT, Fantini GA (1992) Hypothermia relieves oxidative stress in reperfused skeletal muscle following partial ischemia. J Surg Res 53:408-416 